\title{
Nursing History
}

\author{
Marian McMahon
}

\section{Soignant l'histoire/l'histoire de l'infirmière}

Ce texte, tiré d'un film Nursing History, met en jeu le travail déconstructif de la mémoire, une répétition des événements du passé d'une femme, qui vise à rompre avec la répétition ritualisée de ces événements dans des performances ou des cérémonies, tels le mariage ou la collation de grade de l'infirmière, les deux superposés, des rites où l'on devient femme vouée ì se soumettre aux besoins des autres. 
They were moving on toward a resolution of something that had been started for them centuries before

What did you know about this past except that it didn't have anything to do with this your most important day
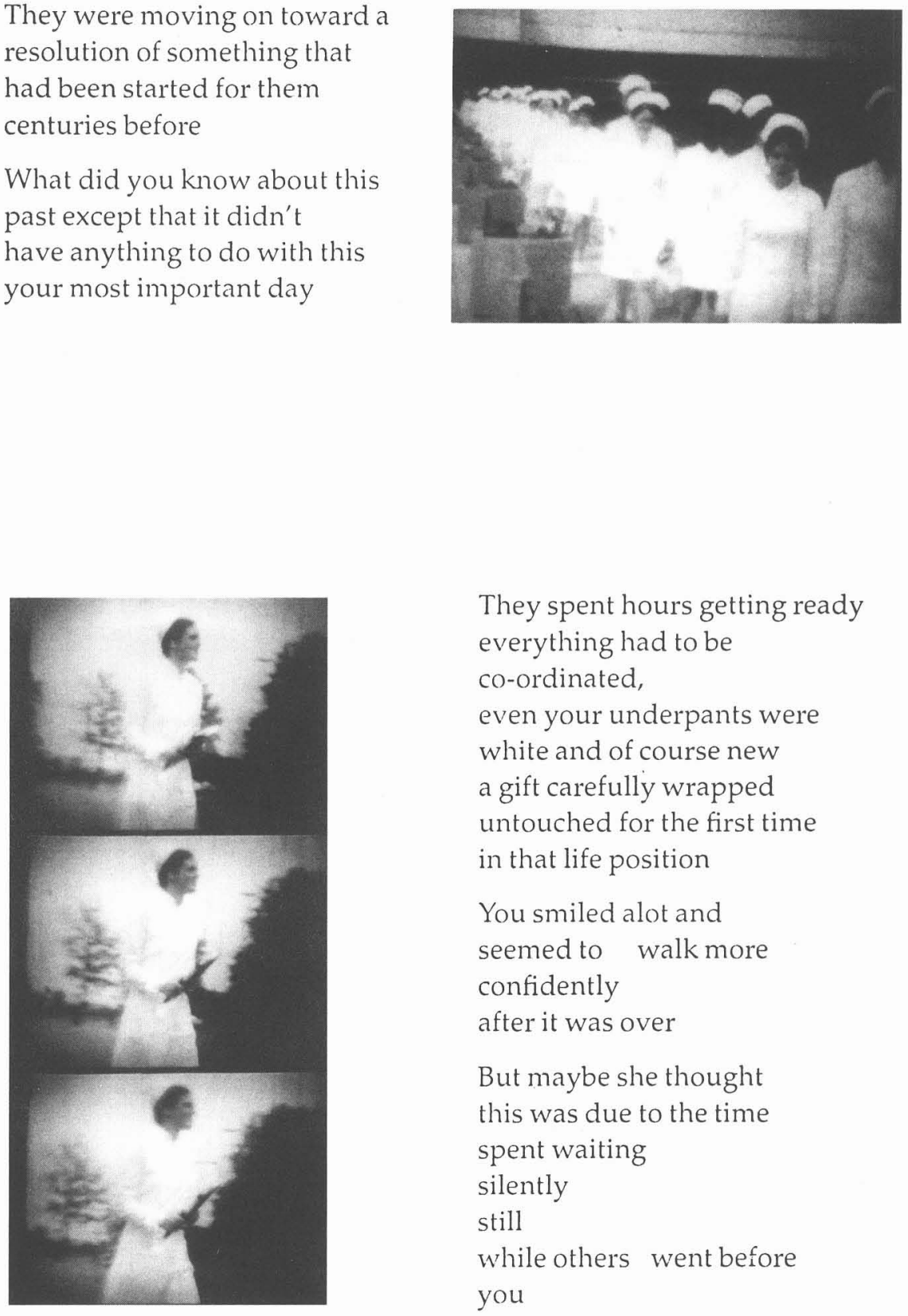

They spent hours getting ready everything had to be co-ordinated, even your underpants were white and of course new a gift carefully wrapped untouched for the first time in that life position

You smiled alot and seemed to walk more confidently after it was over

But maybe she thought this was due to the time spent waiting silently still while others went before you 
It wasn't clear in her mind

but anyway

it didn't matter - you were just relieved

it was over

So much time spent preparing, making sure everything

was right

only to be anxious for it all to be finished

You weren't used to all this attention

and frankly

it made you a bit embarrassed

and do funny things

- maybe she didn't really know how to act

It was hard to keep everything under control

but she was there to help you

Passing between these two men

you caught yourself in a moment of aloneness

- looking at yourself, looking at yourself

avoiding the familiar reflection

of their familial gaze

Suspended in time and space

it was unfamiliar

it was cool,

damp flowing hot green steamy solitude -

nothingness but you

You remember that moment (at times)

but afterwards there's too much to do to

remember well,

to rehearse that moment so it burns

- in your mind

She has trouble recalling that essence

and nothing around her now

seems anywhere near it

or capable of refreshing - her mind

You find that moment full of dangerous pleasure

alone with you

with a presence you can't define

- that frightens her

and she reaches out

to what life is serving her next

and realises that,

maybe she has an appetite for it after all 
She smiles again automatically remembering for that moment what she must do and offers herself to be kissed, to be touched, to be looked at

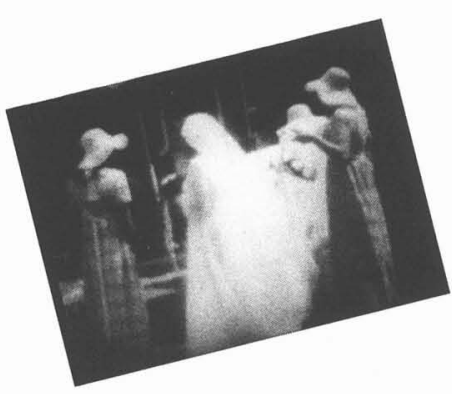

- this is not dangerous

- this is safe

- this is familiar

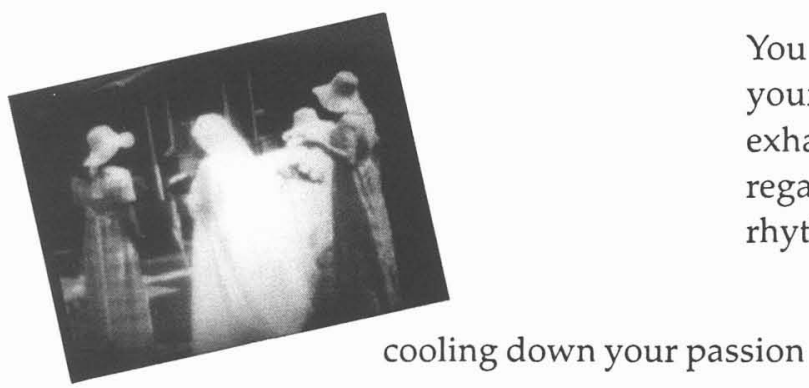

You walk toward a future that your past

has thoroughly predicted and yet you feel you are entering a new world and somehow you manage to make it work

And she keeps trying

to get it right

It looks perfect and everyone follows you with their eyes with their hearts for this most public private moment

And they all watch for the same thing - not knowing what lies beyond this image, underneath its two dimensions, and beyond its static frame Lies that have made them know what they see is real - you can see it for yourself can't you - lies that make them realise it is real

We rely on these images not to confirm our suspicions but to lay them to rest firmly, flatly once and for all 
But her suspicions come back now and I know them and they are coming with a ferocity she can no longer control or ignore

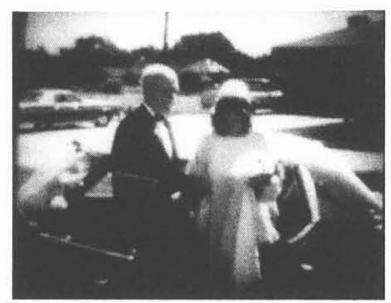

But history

tells her more often

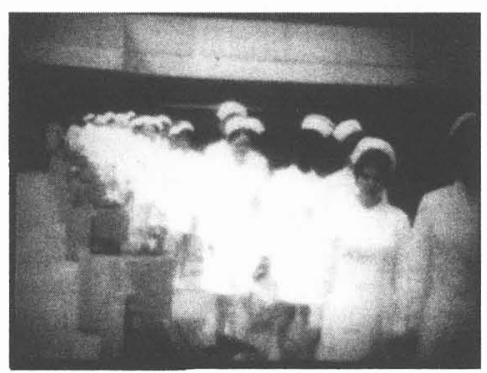

She looks back at the past

to see

where these suspicions came from or if she ever learned anything that would help her understand

even in the face of my knowable and real experiences

She looks back at a uniform past in the face of a fragmented presence there is fear terror and fury

She tries to sleep but it's too noisy and she thinks the sun is shining she sleeps unevenly - disturbed rest she wakes up short of breath short of breath and

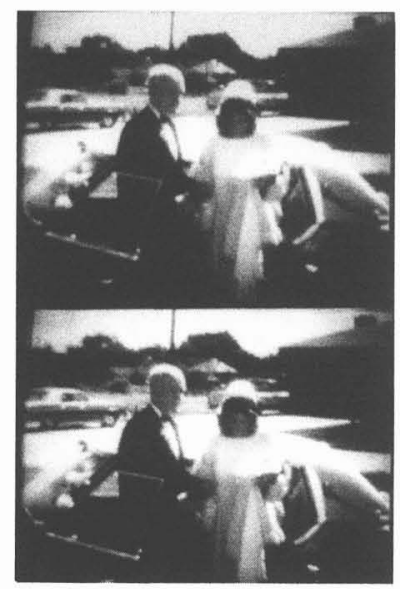
hears her heart pound 
24. Tessera

Lying in perfect pain she

dreams herself awake

and there is something

glowing beneath the surface

It has been there for centuries 